\title{
AUTOEFICACIA DEL SUJETO ACTIVO DEL HECHO PUNIBLE FRENTE A LOS ACUERDOS REPARATORIOS*
}

\author{
Jesús González** \\ Paola Lauretti***
}

\begin{abstract}
Resumen: La prosecución del proceso penal por vía del acuerdo reparatorio comporta acciones influenciadas por el sentido de autoeficacia poco perceptibles a la justicia, de allí que este trabajo se plantee analizar las implicaciones de la autoeficacia del imputado dentro de la justicia penal reparadora. Su desarrollo, se inicia develando el carácter normativo impreso en las nociones de actor activo del delito y de justicia reparadora. Seguidamente, examina el carácter de los acuerdos reparatorios y su tipificación penal explicitando su naturaleza auto- compositiva, y finalmente precisa las incidencias entre
\end{abstract}

* Este artículo corresponde a un avance de la Investigación titulada "Los acuerdos reparatorios en el proceso penal venezolano durante el período 2000-2017”.

** Abogado y Licenciado en Ciencias Políticas y Administrativas. Magíster en Ciencias para el Desarrollo Estratégico. Magíster en Ciencias Políticas y Derecho Público. Doctorando en Ciencia Política de la Facultad de Ciencias Jurídicas y Políticas de la Universidad del Zulia. Docente-investigador en el área de las Ciencias Humanas y Sociales; Zulia, Venezuela. Correo-e: jealgourd2014@ gmail. com.

*** Licenciada en Educación. Magíster Scientiarum en Psicología Educacional. Doctora en Historia de las Américas en la Universidad Complutense de Madrid. Profesora Titular adscrita al Departamento de Psicología de la Escuela de Educación en la Facultad de Humanidades y Educación de Luz en condición de jubilada; Zulia, Venezuela.Correo-e: plaurettis@ hotmail.com. Fecha de recepción: 15 de mayo de 2017. Fecha de aceptación: 15 de enero de 2018. Para citar el articulo: Jesús GonZÁLEZ, PaOla LauretTI. "Autoeficacia del sujeto activo del hecho punible frente a los acuerdos reparatorios", Revista Derecho Penal y Criminología, Vol. 38, n. ${ }^{\circ}$ 105, julio-diciembre de 2017, Bogotá, Universidad Externado de Colombia, pp. 127-158. DOI: https://doi.org/10.18601/ 01210483.v38n105.06 
la autoeficacia y el sistema de justicia penal reparador, señalando que en la reparación la autoeficacia del imputado es clave para respetar obligaciones, concluyendo que la misma evita la inobservancia de acuerdos.

Palabras clave: Proceso Penal, Acuerdo reparatorio, Autoeficacia del Imputado, Actor Activo, Justicia reparadora.

\title{
SELF-EFFICACY OF THE ACTIVE SUBJECT OF THE PUNISHABLE ACT AGAINST REPARATORY AGREEMENTS
}

\begin{abstract}
The prosecution of the criminal process through the reparatory agreement involves actions influenced by the sense of self-efficacy not perceptible to justice; hence this work is intended to analyze the implications of the defendant's self- efficacy within the restorative criminal justice. Its development begins by revealing the normative character included in the notions of active actor of crime and restorative justice. Next, it examines the nature of the reparatory agreements and their criminal classification, explaining their self-compositional nature, and finally specifies the incidents between selfefficacy and the restorative criminal justice system, noting that in reparation the defendant's self-efficacy is key to respecting obligations, concluding that it avoids the non-observance of agreements.
\end{abstract}

Keywords: Criminal Process, Reparatory Agreement, Self-Efficacy of the Imputed, Active Actor, Reparative Justice

\section{INTRODUCCIÓN}

El sistema de justicia penal acusatorio que impera en Venezuela a partir de 1998 con la promulgación del Código Orgánico Procesal Penal (COPP), reformado de manera parcial durante $2000,2001,2006,2009$, y totalmente en 2012, introduce una nueva institucionalidad jurídico-penal con la cual se intenta propiciar la realización de la justicia accesible, expedita, idónea y oportuna, así como la asignación de una pena proporcional o en mayor correspondencia con el delito infligido, donde el esquema de justicia penal se encamina hacia la reparación del daño, abriéndose de esta manera al concurso de soluciones penales distintas a la privación de libertad por voluntad de la víctima del hecho punible con consentimiento del Fiscal de Ministerio Público y del Juez de la causa sobre delitos básicamente de carácter patrimonial y los de tipo culposo.

Es importante referir que el fin de la pena impuesta al autor o perpetrador de un hecho punible cometido es restablecer el daño causado, el cual es constitutivo de alteración del orden establecido por el Estado para lograr la preservación o protección de los bienes -vida, libertad, integridad fisca, propiedad privada-, el mantenimiento de 
la paz social y la sana convivencia de los ciudadanos, cuya exigencia de punición depende básicamente de la gravedad causada a los bienes tutelados - un homicidio calificado es mayormente reprochado por la sociedad que el hurto simple de un bien, y su resultado es máximamente dañoso en virtud de afectar un bien que una vez que se ha lesionado no puede reponerse nuevamente con penalidad alguna-, la intencionalidad con la cual se realizó el daño efectuado, el grado de participación -autor, coautor, colaborador-y los medios para perfeccionarlo o realizarlo.

En el marco institucional referido, los acuerdos reparatorios se tienen como una fórmula de solución alterna a la pena que cumplen con la función de indicarle la responsabilidad a los victimarios de las consecuencias de sus propios actos, implicando desde el punto de vista procedimental y cognitivo-conductual que los mismos lleguen a reconocer sus delitos ante la sociedad efectuando la respectiva reparación del daño producido. En este sentido, desde la propia justicia penal reparadora se produce la reducción del sentimiento de autoeficacia personal al predicar y afear asiduamente en el victimario o actor activo su delito, generando con ello retroalimentación de la imagen negativa, contexto psico-social y jurídico incapaz de motivar a cualquiera para implicarse en honrar una tarea moral/legal como es el cumplimiento de los acuerdos reparatorios suscritos con la víctima.

La autoeficacia o el conjunto de creencias en las capacidades propias para llevar acciones o actividades necesarias a fin de obtener resultados deseados está en consonancia con los propios valores personales en virtud que el sujeto interpreta su conducta con base en un sistema de creencias -favorables o desfavorables- y valores -de acercamiento que le indican lo más importante para sí mismo, así como las acciones con las cuales alcanza mayor placer, y de retirada los que tienden a fijar la atención en determinadas circunstancias de la vida diaria con la intención de evitar el sufrimiento- ${ }^{1}$, así en el campo específico de la justicia penal reparadora los valores de acercamiento como la seguridad pueden llevar al sujeto a prestarle mayor atención a su inocencia que a la presunta víctima o en otro caso - de desvalimiento- volverse hostil por hallarse perdido o abrumado. Así, se indica que

... las transgresiones... pueden dar lugar a una estimulación aversiva de génesis interna, como, por ejemplo, cuando la conducta del que actúa no consigue satisfacer determinados criterios o valores que tiene adquiridos de antemano. En este caso, la estimulación de génesis interna puede reducirse o desaparecer en virtud de las respuestas de autocastigo (por ejemplo, las autocríticas) o al

1 Véase sobre este respecto a Manolete Moscoso, "Hacia un análisis cognitivo del cambio conductual: El comportamiento social proactivo". Revista de Psicología, Vol. XIV, n. ${ }^{\circ}$ 1, 1996, p. 58. 
intensificar el sujeto sus esfuerzos por restablecer los refuerzos positivos que se administra a sí mismo².

Aquí se hace oportuno referir que cuando un sujeto ejecuta una conducta dañosa, cometiendo una acción delictiva o fraudulenta contra las personas, la norma establecida o el propio Estado, revelándose como un antisocial o delincuente, no ha obrado por mero acto de desprendimiento moral sino que tal conducta exteriorizada se vincula directamente a los estándares de su escala de valores personales, los cuales actúan como máxima fuente de motivación de la conducta agresora desplegada y de la autosatisfacción o gratificación personal en el acto dañoso infligido - al estar percibiendo que obtiene recompensas de valor para su vida- lo que despierta, según el criterio teórico la percepción de autoeficacia que tiende a superar todos los controles y límites morales desde donde opera la ejecución de la conducta delictual en cadena ${ }^{3}$.

El comportamiento delictual, antisocial y hostil tiene como epicentro de su accionar la desvinculación moral - procesos psicológicos que favorecen el quebrantamiento de las normas, donde se tienen como principales referentes las percepciones distorsionadas, el ajuste de la escala de valores que actúa como estrategias autojustificadora para acometer la acción y la no actualización o acallamiento de la conciencia- el sentido de autoeficacia -la creencia sobre su capacidad para implicarse en la tarea delictuosa con el que se puede iniciar, mantener o consolidar el aprendizaje delictivo- y la existencia de motivación concreta, la cual se vuelve determinante para el comportamiento transgresor si la tarea se considera sencilla, y en caso de no serlo se requerirá especificidad que proviene del aprendizaje diferencial ${ }^{4}$.

En un entorno institucional desfavorable -en el sentido que tiende a hacer un mayor énfasis en el daño realizado, por consiguiente en la pena o castigo a imponerle que en sus condiciones psicosociales para cumplir sus responsabilidades, sin llegar a reincidir en la acción antijurídica- así como un bajo nivel o sentido adverso al positivo de autoeficacia general -en el cual el sujeto se considera capaz para ejercer un esfuerzo constante sobre las tareas asignadas que le permita conseguirlas con éxito- y de campos específicos referidos fundamentalmente a emprender cambio personal, a evitar la delincuencia, a llevar una vida convencional u honrada, incide desfavorablemente en el desarrollo o ampliación de las competencias personales del victimario para enfrentar con éxito los retos que le impone el sistema penal, indicándose en tal sentido que

2 Bandura, Albert; Richard Walters, R., Aprendizaje social y desarrollo de la personalidad. Madrid, Alianza Editorial, 1974, p. 155.

3 Véase el trabajo de Bandura, Albert, Pensamiento y acción. Fundamentos sociales, Barcelona, Ediciones Martínez Roca, S.A., 1987, donde se refiere que el comportamiento moral depende del propio sujeto.

4 Garrido, Eugenio; Carmen Herrero, Jaume Masip, “Autoeficacia y Delincuencia”. Psicothema. Vol. 14, Universidad de Salamanca, 2001, pp. 63-71. 
El desarrollo de la percepción de autoeficacia es fundamental para desarrollar la capacidad de orientar la conducta hacia metas y objetivos propios y de esforzarse para conseguirlos, con la suficiente persistencia y eficacia para superar los obstáculos que suelen presentarse ${ }^{5}$.

El sentido de eficacia del victimario en el marco de la justicia reparadora se constituye en una variable psicosocial determinante de lo que ha de ser su desenvolvimiento futuro frente a las circunstancias que se le presentan, ya que sus creencias, juicios $\mathrm{u}$ opiniones positivas o favorables le generan seguridad o convicción que puede ejecutar la conducta requerida para producir resultados deseados frente a la tarea pretendida -honrar acuerdos y no reincidir-así que si el victimario del hecho punible piensa que realmente es capaz de admitir el delito imputado, cumplir íntegramente las obligaciones que resultan del acuerdo establecido con aval de Fiscal y juez de la causa y no volver a delinquir, se imaginará un logro efectivo de tales metas, persistiendo en sus esfuerzos por alcanzar lo deseado, y en razón a ello se apuntala que

La autoeficacia funciona como predictor de la conducta y es un poderoso factor determinante. El sujeto con elevadas expectativas de autoeficacia difiere del sujeto con bajas expectativas, a nivel de pensamientos, sentimientos y actuación. Por otro lado, la creencia del sujeto respecto a la dificultad de la tarea puede incidir de forma poderosa sobre el rendimiento ${ }^{6}$.

En relación con este aspecto en particular, el teórico del área ${ }^{7}$ postula que las personas deben tener un sentimiento de autoeficacia fuerte para que su esfuerzo sea lo suficientemente constante o tenaz, permitiéndole alcanzar el éxito, de lo cual se infiere que no basta que el sujeto posea sentido de autoeficacia para realizar la acción, que en el campo del sistema penal reparatorio objeto de interés vendría a ser sentimiento de autoeficacia hacia el cambio, sentido de autoeficacia respecto a la capacidad de evitar la delincuencia, autoeficacia para llevar una vida convencional, percepción sobre la capacidad de superar obstáculos que puedan dificultar la adecuación de la vida, y sentido de eficacia para honrar compromisos, sino que se encuentren en un nivel elevado o tiendan a ser fortalecidas desde la propia institucionalidad del sistema penal.

5 Arbex, CARMen, “Modelos basados en el empoderamiento de los adolescentes y jóvenes” en PAD Servicio de Prevención de Adicciones. Francisco Lobo, Mari GonzÁlez, Madrid (España), Departamento de Prevención, Instituto de Adicciones de Madrid Salud, Ayuntamiento de Madrid, 2012, pp. 32.

6 Garrido, IsAaC; CARMEn Rojo, “Motivación, cognición y rendimiento". Revista de Psicología General y Aplicada. Vol. 49. n. ${ }^{\circ} 1,1996$, pp. 6.

7 Bandura, Albert, "Perceived self-efficacy in the exercise of personal agency. The Psychologist". Bulletin of the British Psychological Society, Vol. 2, 1989, pp. 411- 424. 
Ahora bien, las percepciones de la autoeficacia o competencia en cualquier sujeto se desarrollan a través de logros acerca de su desempeño previo, experiencias vicarias o aprendizaje por observación, persuasión verbal sobre el desempeño que puede ejecutar, y estados fisiológicos y emocionales positivos asociados con el desempeño alcanzado, que en el ámbito del sistema de justicia penal, bien a través de la procedencia de los acuerdos reparatorios sobre causas donde tienen lugar o el encarcelamiento por incumplimiento, van debilitándose en virtud de reforzar la propagación de estados emocionales negativos, no disponer de una estrategia para constituir la percepción de cómo no volver a caer y qué es lo que debe hacerse para poner en práctica sus buenos propósitos, provocando la reincidencia o el abandono definitivo del cambio iniciado ${ }^{8}$.

En las condiciones que opera y se gestiona la realización de la justicia penal reparatoria en el país, es posible establecer analogía o similitud con los efectos de disminución o debilitamiento ocasionados al sentido de eficacia personal por el encarcelamiento o privación de libertad, medida coercitiva la cual tiene claras consecuencias negativas a razón de la propia estigmatización llevada desde el binomio institucionalidad/ sociedad y por la pérdida que ello implica de los apoyos y vínculos existentes con anterioridad para el sujeto victimario, en este sentido si el objeto de la justicia reparatoria o restaurativa como se ha reseñado ${ }^{9}$ no se constituye la individualización de un culpable sino la recuperación del sujeto para la sociedad, han de replantearse las prácticas ejercidas sin quebrantar los valores medulares de la justicia material que se desea impartir a los victimarios o perpetradores de delitos.

El modo en que el sujeto victimario percibe e interpreta al sistema de justicia penal reparadora determina la forma como responderá ante el mismo, evidenciando acatamiento de las normas, incumplimiento de acuerdos, reincidencia delictual o algún otro comportamiento, de allí que se halla referido atinadamente en los estudios realizados ${ }^{10}$ que el éxito en el comportamiento pro-social no reincidente va acompañado de un refuerzo social, autoeficacia, y valoración positiva del entorno en general, dimensiones todas que se sintetizan en la generación de la propia autoeficacia, por cuanto el refuerzo social suele materializarse con la persuasión verbal recibida y el modelamiento, el sentido de eficacia personal con los logros de ejecución, y la

8 Véase a este respecto lo reseñado por GARRIDO, EugEnIO, Justicia Restauradora y Autoeficacia, 2008.

9 MÉNDEZ, YoAHANA, Actitudes hacia la justicia restaurativa y estrategias de afrontamiento en jóvenes vinculados al sistema de responsabilidad penal adolescente (SRPA), Trabajo de Grado para optar al Título de Magíster en Psicología Jurídica, Bogotá, D.C., 2014, pp. 1-173.

10 Menéndez, Belén; María Rodríguez; Carlos Becedóniz; Ana Bernardo, "Influjo del contexto escolar y grupo de iguales en el comportamiento reincidente de menores infractores", en Psicología jurídica. Entorno Judicial y Delincuencia, RodríGuez, Francisco; CARolina Bringas; Francisca FAriña; Ramón Arce; Ana Bernardo (eds.), Oviedo, Ediciones de la Universidad de Oviedo, 2008, pp. 206-212. 
valoración positiva mediante los estados fisiológicos -reacciones bioquímicas y emocionales- que genera la experiencia.

La autoeficacia personal del victimario juega un destacado rol en el cumplimiento de los acuerdos reparatorios, en tanto que las prácticas de la justicia reparadora tienen un papel en el desarrollo de la misma, de allí que el objeto fundamental de este trabajo sea analizar las implicaciones psicosociales e institucionales de la autoeficacia del sujeto activo del hecho punible y el sistema de justicia penal reparadora que se configura a través de los llamados acuerdos reparatorios en Venezuela, lo cual reviste de gran valor gnoseológico en el campo del Derecho Procesal Penal y la Criminología al dejar en evidencia los efectos perniciosos de muchos comportamientos institucionales -que aunque no reconocidos los ejecutan funcionarios del sistema de justicia en su condición de autoridad- frente a los sujetos activos de un hecho punible por el simple hecho de estar presuntamente incurso en un delito.

En el ámbito social permite elevar la voz para dar a conocer las implicaciones criminógenas de una autoeficacia negativa que al ser reforzadas por los comportamientos del sistema penal potencian las acciones del delincuente competente e inducen a debilitar el sentido de autoeficacia positiva del victimario inexperto para consumar crímenes de cualquier índole, lo cual los insensibiliza, los hace mayormente inseguros para lograr resocializarse en su medio o entorno social y los vuelve cautivos o expectantes para entrar a ejercer la delincuencia como forma de vida; en tal sentido, este trabajo ayuda a sensibilizar al público comprometido con la impartición de la justicia penal así como la población en general sobre la problemática planteada, presentando una visión particular del caso que se fundamenta en las impresiones experimentadas en el ejercicio profesional, así como en estudios realizados.

Desde el punto de vista científico-académico, cobra vital importancia por cuanto pretende ser el punto de partida que sirva de soporte para sustentar en el futuro el desarrollo de estudios encaminados al diseño y validación de inventarios de autoeficacia general y específica de los autores de un hecho punible, los cuales sirven como instrumentos de medición confiable para determinar el nivel de seguridad que poseen los victimarios en asuntos claves como el sentido de autoeficacia respecto a la capacidad de evitar la delincuencia, sentido de autoeficacia respecto al cambio, percepción sobre la capacidad de superar obstáculos que puedan dificultar la adecuación a la vida, autoeficacia respecto a la capacidad de llevar a cabo una vida convencional, así como también la realización de estudios dirigidos a precisar con mayor énfasis los tipos de autoeficacia que permiten predecir el desempeño futuro de los victimarios.

Igualmente resulta oportuno referir que el trabajo que se presenta en esta oportunidad se caracteriza por exhibir alcance contemporáneo en virtud de abordar una problemática del presente, escasamente considerada en Latinoamérica -son casi inexistentes los trabajos que aluden la autoeficacia delictual o del autor del hecho 
punible- y que en sí se vuelve apreciable en campo interdisciplinario y transdisciplinario - específicamente en el área del Derecho Procesal Penal y la Criminologíaal llegar por una parte a actualizar en uno de sus apartados el estado del arte sobre los acuerdos reparatorios -los cuales pese a ver sido instituidos en el ordenamiento jurídico venezolano desde hace un buen tiempo los trabajos realizados sobre tal tópico son muy escasos y se encuentran desactualizados-, y por otra parte a integrar las interrelaciones de la autoeficacia de los sujetos en situación de imputado con el sistema penal.

El alcance del objetivo central de este trabajo es efectuado mediante el desarrollo de los siguientes subcapítulos, a saber: Actor activo del delito y justicia reparadora, apartado tendiente a dejar sentado el carácter normativo que se le imprime a las nociones de actor activo del delito y de justicia reparadora en la legislación vigente, el cual se hace menester para prever los comportamientos asumidos por el victimario o actor principal del hecho punible así como de la institucionalidad; Acuerdos reparatorios y tipificación penal, subcapítulo que entra a examinar el carácter de los acuerdos reparatorios y su tipificación penal a los fines de explicitar su naturaleza auto-compositiva, previendo su procedencia desde un marco jurídico del tipo reparador, y finalmente aborda la autoeficacia y el sistema de justicia penal reparador con miras a precisar las incidencias de una a la otra y viceversa.

\section{ACTOR ACTIVO DEL DELITO Y JUSTICIA REPARADORA}

El sistema de justicia penal venezolano dentro del sistema político de democracia participativo y protagónico que se erigió a partir de 1999 ha introducido notables transformaciones institucionales, inicialmente con la promulgación per saltun en 1998 del Código Orgánico Procesal Penal (COPP), luego con sucesivas reformas señaladas precedentemente, dentro de las cuales la justicia reparadora se tiene como una de las primordiales en virtud de trastocar el paradigma de justicia inquisidora imperante -cuya solución al delito es la pena o inflexión al dolor mediante el castigo- aperturando la confluencia hacia otras formas de resolución del conflicto penal, con las cuales se tiende a humanizar la justicia e impactar sobre el desescalamiento de la conflictividad social, planteándose que se trata de un

Diseño de Justicia basado en la atención a la víctimas, en una solución no basada en la venganza con pretensiones de habilitar a las víctimas, al infractor y a los miembros afectados de la comunidad para que participen directa

y activamente en la respuesta del delito con la vista puesta en la reparación de la paz social ${ }^{11}$.

11 Villarreal, Karla, "La víctima, el victimario y la justicia restaurativa". Rivista di Criminologia, Vittimologia e Sicurezza, Vol. 7.n. ${ }^{\circ}$ 1, 2013, pp. 45. 
En plena correspondencia con el cambio de paradigma a lo que ha venido siendo el modelo inquisitivo enquistado por décadas en la propia institucionalidad, cultura y patrones normativos del sistema penal venezolano, y a la nueva filosofía jurídico penal adjetiva que sustenta tanto la estructura -esto es el conjunto de instituciones fundadas o erigidas en el propio sistema que conjuga valores, principio y mecanismos de naturaleza fundamental para la convivencia social pacifica- como el funcionamiento -actuaciones, roles y procedimientos desarrollados a los fines de alcanzar la justicia material- se ha venido ratificando en el devenir del ideal de democracia participativa y protagónica el compromiso con la prosecución alterna de los conflictos penales, en este sentido se reconoce institucionalmente que

Nos encontramos así ante nuevos paradigmas, que se encuentran revolucionando la conciencia social, vinculados a la necesidad de transformación de las estructuras y visiones tradicionales, desgastadas por el ejemplo detractor de modelos incompatibles con la realidad nuestra, de manera que se hace impostergable la implementación de paradigmas, como instrumentos de ruptura de los métodos, hasta ahora aplicados, para la resolución de conflictos en el proceso penal $^{12}$.

Así, el Decreto con Rango, Valor y Fuerza de Ley del Código Orgánico Procesal Penal de 2012, pese a tener una orientación autocrática del procedimiento penal por cuanto elimina la participación ciudadana materializada en la figura de los escabinos -ciudadanos comunes que ayudaban a decidir al juez- y en los tribunales mixtos, suprime el derecho de las víctimas a agruparse y delegar el ejercicio de sus derechos en organizaciones no gubernamentales (según lo dispuesto en el artículo 124 eiusdem), y elimina la posibilidad de declarar la improcedencia de la detención del imputado de manera anticipada, llega a ratificar las mismas medidas alternativas a la prosecución del proceso del Código de 1998 con sus respectivas reformas parciales, diferenciándose únicamente en los supuestos de procedencia (acuerdos reparatorios).

En este sentido, el instrumento jurídico adjetivo in comento en lo tocante al reconocimiento de la condición del victimario, el artículo 126 eiusdem procede primeramente asignar el calificativo normativo de imputado o imputada al autor o partícipe de un hecho punible señalado por un acto de procedimiento de las autoridades encargadas de la persecución penal, luego en el segundo aparte de norma refiere que se adquiere la condición de acusado o acusada con la admisión de la acusación, comportando en tal sentido dos situaciones jurídicas distintas, una que hace referencia a la inculpación o señalamiento como hecho fáctico de la persecución penal y la otra atinente a

12 Presidencia De La República Bolivariana De Venezuela. Decreto con Rango, Valor y Fuerza de Ley del Código Orgánico Procesal Penal. Caracas. Gaceta Oficial Extraordinario n. ${ }^{\circ} 6.078$ del 15 de junio de 2012. 
la condición de procesado que se adquiere mediante reconocimiento expreso de la causa; por ello, en relación con este aspecto doctrinariamente se indica que

... una persona puede considerarse en calidad de imputada, luego de realizada la formulación de cargos que da la pauta de inicio de la instrucción fiscal (acto inicial formal de procedimiento o etapa), en donde directamente se le atribuye la realización de un hecho... una persona llevada material y formalmente a juicio (etapa) pasa a ser un procesado, manteniendo esta calidad hasta que obtenga una sentencia ejecutoriada ${ }^{13}$.

En relación con ello, ha de indicarse que en las reformas parciales del Código Orgánico Procesal Penal de 2001 y 2006 se estipulaba que el imputado adquiría la calidad de acusado con el auto de apertura a juicio, circunstancia modificada en la reforma parcial de 2009, y sostenida en la reforma total del mismo acometida en el 2012 al prever que el imputado alcanza la condición de acusado con la admisión de la acusación, variando únicamente en estas dos últimas reformas de sus predecesoras, la redacción de la disposición en lo tocante al acto que dota de calidad de acusado al imputado, lo cual permite equiparar al acusado con el sujeto procesado, toda vez que la admisión de la acusación supone ineludiblemente el pase a juicio, que viene a ser la fase siguiente a dicho acto en el recorrido procesal estipulado en el texto adjetivo penal.

Ahora bien, es oportuno establecer diferencia entre imputado y acusado -circunstancias procesales disímiles de derechos y garantías- con la autoría del delito, la cual alude a la participación o intervención delictual, en tal sentido se ha referido en la doctrina jurídico penal ${ }^{14}$ que el imputado es "aquella persona contra quien se dirige la pretensión penal", y que desde el punto de vista del principio de presunción de inocencia necesita defenderse de la carga delictual imputada, en tanto que el acusado entra a ser el sujeto procesado desde el auto de apertura a juicio, equivaliendo ello a la categoría de autor del delito cometido, ya que en esta fase existen elementos de convicción suficientes para conllevar su acusación, constituyéndose así, según los estudios del área ${ }^{15}$,"en la figura central del hecho perpetrado", haciéndolo extensivo hacia el propio proceso, por tal razón se afirma que

Al Estado siempre le ha interesado el delincuente por ser éste quien ha lesionado o puesto en peligro los bienes jurídicos que aquél tutela a través de la

13 Xavier Andrade, X., "Consecuencias jurídicas de los derechos del procesado derivadas de su operatividad constitucional”. Iuris Dictio, Vol. 15, Quito, Universidad de San Francisco, 2013, pp. 132.

14 Binder, Alberto, Introducción al Derecho Procesal Penal. Buenos Aires, Editorial Ad- Hoc S. R. L., 1998 , pp. 310.

15 Roxin, Claus, Autoría y Dominio del hecho en el Derecho Penal. Madrid, Ed. Jurídicas y Sociales, 2000. pp. 44. 
norma penal... la persecución penal, responde a su interés de ver castigado al victimario ${ }^{16}$.

Así pues, en el campo de la justicia penal reparadora, las vías previstas para su realización están concebidas en primer orden para subsanar la situación gravosa del sujeto pasivo del delito, por lo tanto se le tiene como la figura estelar de la misma, no obstante al sujeto activo o autor del delito se le considera un benefactor colateral toda vez que con el arribo de un posible arreglo con la víctima desde la fase preparatoria -instrucción de la causa mediante proceso de investigación y recolección de todos los elementos de inculpación- hasta después de la presentación de la acusación del representante del Ministerio Público, donde se llega a prescindir del proceso penal, evitando los males de una sentencia condenatoria -no padecerá condena penal ni quedará estigmatizado como delincuente- en tal sentido se considera que

... le otorga una herramienta al imputado, con la cual pueda resarcirle de alguna manera el daño causado a la víctima, brindándosele a su vez la oportunidad de reinsertarse a la sociedad, sin tener que sufrir el rigor de cumplir una pena privativa de libertad, en uno de los centros de reclusión de este país, que lejos de rehabilitar al interno los etiqueta y los encamina por la senda del delito ${ }^{17}$.

En la perspectiva planteada, la finalidad de la justicia penal reparatoria es darle oportunidad a quien cometió un hecho punible -llámese sujeto activo, perpetrador o autor del delito- de asumir la carga de sus actos, enmendando con justa indemnización el daño cometido al ofendido, hecho constitutivo de resocialización en virtud de favorecer la reinserción o la reeducación del transgresor a la vida social, sin llegar a darle un contenido instruccional sino moralizante expresado en el reconocimiento de la norma -implicaciones de su trasgresión-, el sentido de responsabilidad para reconocer el perjuicio comprometiéndose a enmendarlo y a transitar desde ahora con una vida sin delitos, aspectos de inapreciable proceder pero insuficientes para garantizar la no reincidencia delictual al no considerarlo en todo su potencial, por ello se afirma que se trata

... de un problema del sistema penal en su conjunto, de los fines que se persigue y de las tareas que abarca el derecho penal, y, por fin, de los medios de realización que para alcanzar esos fines y cumplir esas tareas pone a dis-

16 Han, Pablo; Jesús PÁrraga; María Scarano, "Los Acuerdos Reparatorios y su aplicación en el nuevo proceso penal venezolano". Capítulo Criminológico, Vol. 28, n. ${ }^{\circ}$ 2, Maracaibo, Universidad del Zulia, 2000. pp. 33.

17 Han, Pablo; Jesús PÁrraga; María Scarano, "Los Acuerdos Reparatorios y su aplicación en el nuevo proceso penal venezolano". Capítulo Criminológico, Vol. 28, n. ${ }^{\circ}$ 2, Maracaibo, Universidad del Zulia, 2000. 
posición el derecho procesal penal... se trata en (síntesis) de un problema político criminal común, al que debe dar solución el sistema en su conjunto ${ }^{18}$.

El autor del delito, por ser quien lesionó algún bien jurídico tutelado por el Estado - caso particular patrimonio, vida, salud e integridad física los cuales se reconocen, garantizan y preservan en forma diseminada en el ámbito penal sustantivo con la tipificación de los delitos patrimoniales, culposos y las lesiones culposas, donde operan los acuerdos reparatorios por disposición expresa de la norma procesal o adjetiva-, se ve relegado a un papel pasivo, secundario o poco significativo, donde su condición de sujeto con derechos está condicionada a la de procesado; en razón a ello se cuestiona la participación voluntaria y la previa declaración de responsabilidad del autor ${ }^{19}$, quien puede verse obligado acoger un acuerdo que considera injusto ante el temor de ser inculpado por un sistema de justicia totalmente punitivo ${ }^{20}$.

\section{ACUERDOS REPARATORIOS Y TIPIFICACIÓN PENAL}

Los acuerdos reparatorios son una alternativa a la pena privativa de libertad que se introduce en el sistema penal venezolano a partir de la promulgación del Código Orgánico Procesal Penal (COPP) en 1998, cuya génesis de inspiración se ubica en las modernas tesis doctrinarias del Derecho penal adjetivo como el garantismo penal, que aboga por una pena mínima, mínimo sufrimiento o pena menos martirizante para el autor del delito; la justicia reparadora, la cual propugna que la función principal de la justicia penal per se no es castigar, sino crear las condiciones para una compensación razonable de los perjuicios propinados a la víctima ${ }^{21}$, y la resocialización ${ }^{22}$

18 Maier, Julio, "La Víctima y el Sistema Penal". Jueces para la Democracia, n. . 12, Madrid, 1991, pp. 33.

19 Como precisa BÁrcenas, Edgar, "Definición de la responsabilidad”, Médico- Legal On-line Revista Colombiana para los Profesionales de la Salud, vol. xx, núm. 1, s./f, pp. 2, el Derecho penal se fundamenta en las nociones de responsabilidad objetiva y subjetiva, donde es exigible un comportamiento conforme a la ley que al verificarse en los criterios jurídico- penales y quedar demostrado el dolo y la culpa en el sujeto que cometió la acción se le impone una pena.

20 ARÍAs, DORIS, "Reflexiones teóricas y prácticas sobre la reparación del daño y la justicia restaurativa" en Justicia restaurativa en Costa Rica: Acercamientos teóricos y prácticas. F. BERNAL, S. CASTILLO (Comp.), San José, Comisión nacional para el Mejoramiento de la Administración de Justicia, 2006, pp. 164-185.

21 Según refiere CHAPARro, AyAr, "Ensayo Características y Conceptos de la Teoría Finalista del Delito", Capítulo Criminológico, vol. 28, num. 2, 2000, pp. 106, la idea de los arreglos particulares en el derecho penal se remonta desde la antigua Roma con la retribución (talonial) y de la indemnización (damnum, poena), donde se concebía la pena como una deuda y un pago.

22 Al revisar el trabajo de MALAGUERA, JosÉ y NELSON GARRIDO, “Justicia penal alternativa (reparatoria) Breve análisis de algunos sistemas latinoamericanos”, Revista CENIPEC, num. 28, 2009, pp. 194- 195, se llega apreciar que tales posiciones se corresponden con las concepciones político- criminales de las tesis abolicionista, garantista y resocializadora. 
amparada en la idea de evitar una pena que genere sentimientos de minusvaloración, resentimiento y frustración que lleven al autor del delito volverse contra la sociedad en un futuro.

Ahora bien, dentro del ordenamiento jurídico venezolano se concibe a los acuerdos reparatorios como una forma de auto-composición procesal, en virtud de ser expresión directa de la manifestación de voluntad libre y consciente, entre el imputado -que si bien es cierto el mismo se encuentra bajo el auspicio de punición que eternamente entraña al proceso penal tiene la posibilidad de dar su consentimiento o negarse hacerlo- y la víctima, adquiriendo así carácter de negocio jurídico penal bilateral perfecto por cuanto comporta obligaciones para ambas partes -el imputado debe reponer pecuniariamente en forma íntegra, proporcional y responsablemente por el delito cometido, en tanto que la víctima debe aceptar sin mayor reparo el resarcimiento producto de las estipulaciones del propio acuerdo-; a tal respecto se indica que

... es un convenio judicialmente aprobado en un proceso penal concreto, entre quien funge como imputado y la víctima o víctimas del delito juzgado, por lo cual el primero se compromete a satisfacer la responsabilidad civil proveniente de dicho delito, vale decir, que el imputado se obliga a pagar los daños materiales y morales, y los perjuicios que su acción delictiva haya acarreado ${ }^{23}$.

En tal sentido, es oportuno referir que en el desarrollo normativo contentivo del Decreto con Rango, Valor y Fuerza de Ley del Código Orgánico Procesal Penal de 2012, se le confiere reconocimiento expreso a la reparación del daño causado a la víctima del delito como objetivo del proceso penal (artículo 120 eiusdem), dándole acogimiento a la figura de los acuerdos reparatorios de naturaleza auto compositiva y a la acción civil para la restitución, reparación e indemnización de los daños y perjuicios causados por el delito cuyo carácter es eminentemente heterocompositivo -en virtud de intervenir una voluntad extraña al de la víctima para resolver el conflicto penal- requiriéndose para su activación de un acto jurídico penal previo, como es la existencia de una sentencia definitivamente firme de condena, calificándose a tal respecto de:

... una causa de naturaleza penal por atribución, por derivar de una sentencia penal definitivamente firme, considerando tal pronunciamiento como requisito de admisibilidad y de procedibilidad, no meramente formal, sino que constituye un presupuesto necesario, por cuanto su exigencia surge de la necesidad de (...) que quede determinado, con certeza, que se ha cometido un hecho punible del cual sea posible alegar y probar que se han generado

23 PÉRez, ERICK, Comentarios al Código Orgánico Procesal Penal, Caracas, Vadell Hermanos Editores, 2001. pp. 53. 
daños y perjuicios, asimismo, quién es la persona que ha de responder, ante la víctima, por los correspondientes resarcimientos e indemnizaciones ${ }^{24}$.

En consideración a lo anteriormente planteado, pueden valorarse dos vías, sobre las cuales es preciso advertir que aunque ambas procuran el resarcimiento y se encuentran sujetas a la realización de determinado acto jurídico para concretarse, son totalmente diferentes a los fines de alcanzar la reparación penal. Una de forma voluntaria, donde media la disposición o acto volitivo entre víctima y victimario de acogerse a una resolución alterna a la imposición de una pena de privativa de libertad mediante acuerdos, por la cual puede hablarse de justicia penal por consenso, y la otra de carácter extracontractual que procede por vía jurisdiccional penal cuando se haya decretado sentencia condenatoria y se practique el impulso procesal de la víctima, herederos o el Ministerio Público en caso de delegación.

En razón a que con los acuerdos reparatorios se suprime la pena de privativa de libertad del victimario o autor del hecho punible, se suele pensar erróneamente -dentro del colectivo común- estar en presencia de un acto de impunidad o lenidad de la pena impuesta, cuando la verdadera realidad del asunto es tratar de evitar con ello que se produzca libertinaje e injusticia, cambiando o haciendo aplicación distinta de la vetusta concepción de la pena o el castigo sobre quien ha cometido el hecho ilícito, en virtud de considerar el encarcelamiento como el último eslabón a que debe acudir el operario de la norma penal para impedirle hacer nuevos daños a sus conciudadanos al tiempo que se procura apartar a los otros de emular tal acción delictual como se ha apuntalado ${ }^{25}$, de allí que

... se intenta, sin admitir la impunidad, superar las objeciones al controvertido concepto de castigo, otorgar la posibilidad de un resarcimiento a las víctimas -material o simbólico, pero sin la simbología del mero sufrimiento sino con la simbología del resarcimiento concreto-y disminuir las reincidencias delictivas mediante el logro de un cambio facilitado en los autores de delitos por medios basados en un etiquetamiento inverso al habitual ${ }^{26}$.

El legislador patrio, deseando evitar que los acuerdos reparatorios se vuelvan escapatoria del encarcelamiento que ameritan los delitos gravosos cometidos contra los bienes protegidos por el Estado ${ }^{27}$, los ha revestido de seguridad jurídica, estableciendo

24 Sala Constitucional del Tribunal Supremo de Justicia. Sentencia n. ${ }^{\circ} 776$ del 9 de abril de 2002.

25 Véase el trabajo de BECARIA, CÉSAR, De los Delitos y las Penas. Francisco Tomas (trad.), Madrid, Aguilar Ediciones, 1982.

26 Deym, José, "Crisis actual del Sistema Penitenciario y de la Política Penal”. Pensar en derecho, n. ${ }^{\circ}$ 2, 2016, pp. 239- 282.

27 Al revisar el trabajo de Delfín, Lusvioleth, "Razones de Economía Procesal”, Ministerio Público, vol. 4, num. 8, 2011,pp. 47-49, puede concluirse que desde la perspectiva de la economía procesal 
condiciones objetivas -operan solamente cuando ha ocurrido alguno de los dos tipos penales establecidos, es decir, en delitos contra el patrimonio o delitos culposos contra las personas- y las condiciones subjetivas de procedencia, entre las que resultan la comprobación del juez de estar inmerso en los tipos penales prescritos, consentimiento de la víctima e imputado en forma libre y en pleno conocimiento del derecho que los asiste, la opinión del Ministerio Público, aprobación de nuevo acuerdo sujeto a la prescripción del término establecido, la admisión de hechos y la reparación efectiva.

Así los acuerdos reparatorios operan taxativamente sobre delitos patrimoniales, relativos a la propiedad tales como hurto simple ${ }^{28}$, estafa inmoviliaria ${ }^{29}$, quiebra culposa $^{30}$, apropiación indebida ${ }^{31}$ y usurpaciones ${ }^{32}$, y no sobre los delitos económicos o contra el orden socioeconómico, siendo los primeros los que lesionan directamente los intereses jurídicos del acervo de los particulares, constituido no solamente por el dominio, sino también por la posesión, la tenencia y todo derecho real y obligacional con existencia distinta e independiente de la persona misma ${ }^{33}$, en tanto los segundos son aquellos que lesionan los intereses jurídicos económicos metaindividuales, como el ilícito económico, la especulación, el acaparamiento, la usura, la cartelización, el boicot económico, el agiotaje, el contrabando, la defraudación tributaria, entre otros tipos penales ${ }^{34}$.

la persecución penal suele concentrarse sobre aquellos delitos de mayor relevancia social y penal (mayor desvalor de injusto).

28 Al decir de ArCaya, Pedro, "Los Acuerdos Reparatorios". Relación Criminológica, Núm. 13, Valencia, Universidad de Carabobo, 2005, pp. 61-82, en la comisión del delito de hurto simple, el objeto de la acción está representado por la cosa sustraída cuyo objeto de protección es la propiedad.

29 En el trabajo de LAw, SiRIA, "Penalización de la estafa inmobiliaria según la legislación penal venezolana vigente", Revista del Ministerio Público, vol. 5, num. 12, 2012, pp. 85-102, el tipo penal que define la estafa inmobiliaria, se define como una acción consumada en la que se tuvo la disposición de adquirir un bien inmueble, mediante el contrato de compraventa y transmisión de la propiedad en forma ilegal.

30 Al decir de Valery, Paúl, Curso de Derecho Mercantil, Caracas, Ediciones Liber, 2004, pp. 567, es la ocasionada por una conducta imprudente o disipada por parte del comerciante.

31 En el texto de ARTEAga, Alberto, Estafa y apropiación indebida en la legislación venezolana, Caracas, Talleres Tipográficos de Miguel Ángel García \& Hermanos, 2007, se recoge fielmente al artículo 466 del Código Penal que establece "El que haya apropiado, en beneficio propio o de otro, alguna cosa ajena que se le hubiere confiado o entregado por cualquier título que comporte la obligación de restituirla o de hacer de ella un uso determinado, será castigado con prisión de tres meses a dos años, por acusación de la parte agraviada".

32 Según reseña GonZÁLEZ, CASTOR, "La Usurpación de Marcas en Venezuela. Especial referencia a las medidas de Fronteras". Revista La Propiedad Inmaterial, 2001, pp. 129, "la normativa penal vigente para el caso de la usurpación marcaria, sólo prevé penas de prisión de uno a doce meses, las cuales son automáticamente sustituidas por beneficios procesales establecidos en el ordenamiento jurídico".

33 Sobre el particular consúltese Quintero, GonZalo, Los Delitos contra el Patrimonio, Catalunya, Universitat Oberta de Catalunya, 2012, pp. 11- 68.

$34 \mathrm{Al}$ apreciar el trabajo de DuQue, ANDRÉs, "Apuntes sobre la normativización del Derecho Penal Económico”, Temas de Derecho Económico y Patrimonial, Colombia, Universidad Pontifica Bolivariana, 
Los delitos de contenido patrimonial en los cuales proceden los acuerdos reparatorios se encuentran libres de haber incurrido en violencia contra las personas, los cuales se muestran más cónsonos con la naturaleza reparatoria -el daño ocasionado al ofendido no atenta contra su integridad física y aunque su patrimonio haya sido lesionado, contraído o perturbado momentáneamente en ocasión del consentimiento con el ofensor puede ser resarcido bien vía pecuniaria o con trabajo por los méritos favorables de la justicia penal reparatoria- de tal manera que la exclusión de los delitos dolosos o intencionales - cometidos con intensión, grave violencia o la intimidación personales categórica porque lo deseado jurídicamente es causar el menor daño posible tanto a la sociedad como el Estado, siendo así la conducta lesiva o delictiva insignificante para llegar a ser penalizada corpóreamente, reconociéndose sobre ello que

Es consecuencia evidente del principio de intervención mínima, pero también se explica porque las actuaciones imprudentes sobre el patrimonio ajeno o en la gestión de los asuntos propios del orden socioeconómico pertenecen genuinamente al ámbito del derecho privado y solo los excesos intencionales, y no todos, pueden llegar al derecho punitivo ${ }^{35}$.

Relativo a los delitos culposos es oportuno referir que en ellos no existe la intención (dolo) por parte del perpetrador o victimario de ocasionar el daño a la víctima sino culpa, los cuales son punible excepcionalmente en nuestro ordenamiento jurídico cuando ha mediado la omisión - conducta desprovista del cuidado necesario- la imprudencia o la impericia en virtud de llegar a lesionar bienes jurídicos que considerablemente son protegidos por el Estado, como pueden ser la vida y la integridad corporal (artículos 409 y420 del Código Penal), no obstante la norma adjetiva (artículo 40 del COPP) después de la reforma del 2012 se volvió tan amplia que obvia prescribir totalmente que su procedencia debe ser únicamente sobre los delitos culposos que no se consideraran graves por Ley o que su pena no exceda los 4 años de prisión ${ }^{36}$.

La comprobación del juez que el imputado se encuentre inmerso en los tipos penales prescritos es una condición subjetiva de procedencia sine quanon de los acuerdos reparatorios en virtud primeramente de prevalecer el principio constitucional de legalidad penal, el cual preceptúa que nadie puede ser castigado por un hecho que no estuviere expresamente previsto en ley preexistente como delito o falta (nullum

2018, se deduce que la normativización de nuevos tipos penales surge a razón del comportamiento que lesiona los intereses del Estado.

35 Quintero, Gonzalo, Los Delitos contra el Patrimonio, Catalunya, Universitat Oberta de Catalunya, 2012, pp. 15.

36 En el trabajo de PÉREz, ERIC, Comentarios al Código Orgánico Procesal Penal (Concordado con el COPP de 12 de junio de 2012, Caracas, Vadell Hermanos Editores, 2016, se advierte que la última reforma al Código Orgánico Procesal Penal (COOP) del año 2012 se proscribió los delitos culposos que tengan como desenlace la muerte de la persona o una afectación grave y permanente en su integridad física. 
crimen, nullum poena sine lege previae), pues al hacerlo se estaría frente a la arbitrariedad e injusticia, y como consecuencia inmediata de la verificación de dicho principio está el hecho inequívoco de evitar que se relajen entre particulares normas de orden público, en virtud a que con dichos acuerdos establecidos pudieran presen-

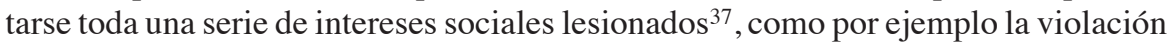
de la propia norma penal.

En el ámbito de la justicia penal reparatoria el consentimiento voluntario y libre de amenazas, error o vicios en los interesados o actores principales es relevante para dar término al conflicto penal surgido de la acción delictual, es decir, debe existir un interés autónomo o de auto-disposición entre la víctima e imputado en celebrar el acuerdo reparatorio, cuya finalidad es resarcir al ofendido del daño acarreado con el tipo penal cometido -que ha de ser de menor gravedad para su procedencia- confiriéndole a la vez al perpetrador la posibilidad de lograr la resolución del conflicto penal con la menor intervención del Estado, donde no queda excluida su responsabilidad porque el mismo se constituye en el garante y defensor del resultado de las estipulaciones fijadas por las partes en el acuerdo, así como en el fiel cumplimiento de ellas, en tal sentido se exige como condición:

... que concurran las voluntades del imputado y de la víctima en el acuerdo, en términos tales que el primero esté dispuesto a reparar el daño causado y el segundo esté dispuesto a aceptar dicha reparación. Lo anterior importa que el imputado y la víctima deben estar de acuerdo (1) en la celebración del acuerdo reparatorio, (2) en la prestación a realizar por parte del imputado, (3) como así también en las modalidades y plazos para cumplirla ${ }^{38}$.

En relación con la admisión de los hechos, es oportuno referir que la suscripción entre víctima y victimario del acuerdo reparatorio supone en principio garantizar el respeto a la dignidad, al debido proceso y a la finalidad del proceso, presunción que deriva de acuerdo a lo estipulado en el artículo 127 eiusdem; no obstante, el artículo 41 eiusdem desvirtúa tales garantías, al disponer que en caso que el acuerdo reparatorio se realice después de que el Ministerio Público haya presentado la acusación, y sea admitida, se requerirá que este, en la audiencia preliminar o antes de la apertura del debate, si se trata de un procedimiento abreviado, admita los hechos de la acusación, que servirán para dictar sentencia condenatoria en caso de incumplimiento,

37 En el trabajo expuesto por Vizcardo, Silfredo, "Principios Reguladores del Control Penal. Las Normas Rectoras", Revista Jurídica Docentia et Investigatio, vol. 11, num. 1. 2009, pp. 49- 72, se infiere que el juez de la causa posee el ius poniendi (derecho de imponer penas o de castigar) del Estado por lo tanto está en la facultad de rechazar toda pretensión o intento de hacer uso indebido o exorbitante de esta alternativa.

38 Videla, Lino, "Los acuerdos reparatorios a la luz del concepto de reparación", Revista de Estudios de la Justicia, n. 13,2010 , p. 304. 
conforme al procedimiento por admisión de los hechos sin rebaja de pena prevista, indicándose que ello es

... contrario a la disposición contenida en el título preliminar relativo a los principios y garantías procesales, toda vez que se está coaccionando al imputado bajo la figura de una presunción que no admite prueba en contrario, a aceptar unos hechos que lo condenan, por el solo motivo de no haber podido dar cumplimiento a una obligación de carácter civil ${ }^{39}$.

En cuanto a la opinión del Ministerio Público para la procedencia de los acuerdos reparatorios entre la víctima y el imputado, ha de destacarse el rol preponderante que el mismo juega en su consecución al llegar a ser el titular de la persecución penal en representación del Estado así como representante de los derechos infringidos a la víctima, constituyéndose en este sentido en un indiscutible garantizador de los intereses protegidos penalmente, por cuando la norma adjetiva le prevé la potestad institucional de emitir su opinión sobre la viabilidad del acuerdo (segundo aparte del Artículo 41 eiusdem), sin que ello se constituya en un contrapeso o freno para la celebración del acuerdo, pues su opinión se limita a exponer la existencia del cumplimiento de los extremos de procedencia previstos en la norma, estableciéndose de esta manera que

... ya no se trata de pedir opinión favorable como en anteriores versiones del código procesal, una dependencia práctica de la opinión favorable del Ministerio Público sobre el acuerdo reparatorio puede atentar contra algunos principios de la justicia penal como el principio de igualdad, ya que antes de escuchar la opinión de la vindicta pública, las partes ya han acordado mediante la oferta, negociación y aceptación, las condiciones que regirán el acuerdo reparatorio, por lo que si una opinión desfavorable contraviniese lo acordado, pondría al Juez a definir qué sujetos procesales tienen mayor peso, creando una especie de coalición entre quienes primeramente estuvieron enfrentados -víctima e imputado- Vs. Ministerio Público ${ }^{40}$.

En atención ahora a lo tocante al lapso para la aprobación de un nuevo acuerdo, ha de indicarse que este se encuentra sujeto a la prescripción del término establecido por norma adjetiva de tres (3) años, de tal manera que si no se ha agotado completamente el período de tiempo que ha de mediar entre el acuerdo previamente celebrado con el que está por suscribirse, este último no podrá celebrarse por improcedente, al contravenir a la norma que estipula precisamente un lapso temporal de equidistancia a los fines de

39 Arcaya, Pedro, "Los Acuerdos Reparatorios”. Relación Criminológica, Núm. 13, Valencia, Universidad de Carabobo, 2005, pp. 78.

40 Fereira, George, El Ministerio Público frente a los Medios Alternos de Resolución de Conflictos como garantía penal para la Víctima. Maracaibo, Universidad Rafael Urdaneta, Trabajo de Grado para optar al Título de Abogado, 2013, p. 81. 
impedirle al victimario en su condición de imputado hacer uso continuo de la institución procesal para evadir la pena de privativa de libertad que amerita el tipo penal o delito cometido contra particulares o propio Estado, haciéndose de esta manera efectiva la rigidez normativa en la preservación de los bienes jurídicos tutelados en sociedad.

La admisión de hechos es un requisito únicamente exigible para la celebración de un acuerdo reparatorio cuando el representante del Ministerio Público ha presentado acusación formal, en virtud de haber llegado a la conclusión en la investigación penal llevada a tal efecto que existen suficientes elementos de convicción que lo incriminan, por lo que resulta procedente la imputación, que se diferencia del procedimiento por admisión de hechos previsto en el Artículo 375 eiusdem por cuanto si bien es cierto que en él también se hace reconocimiento expreso de la intervención o participación sobre el hecho punible establecido, aquí no se efectúa reducción de la pena establecida ni se suele cambiar la calificación del delito, sino que al momento de darle incumplimiento al acuerdo suscrito sirve de prueba irrefutable para imponer la pena correspondiente.

Y, finalmente, la reparación efectiva del daño infligido a la víctima, esto es, el cumplimiento del acuerdo suscrito por el victimario el cual ha sido previamente homologado por el juez de la causa, se constituye en la consumación material que extingue la pena corpórea aplicable al tipo penal o delito perpetrado. En tal sentido, el tercer aparte del Artículo 41 del Decreto con Rango, Valor y Fuerza de Ley del Código Orgánico Procesal Penal expresa taxativamente "el cumplimiento del acuerdo reparatorio extinguirá la acción penal respecto del imputado que hubiere intervenido en él", llegándose así a proceder a declarar el sobreseimiento de forma inmediata, por extinción de la acción penal, con fundamento en el ordinal 6 del Artículo 49 eiusdem, el cual reconoce el cumplimiento del acuerdo como causal de prescripción penal.

\section{AUTOEFICACIA Y SISTEMA DE JUSTICIA PENAL REPARADORA}

En este apartado corresponde analizar el influjo que desempeña en la autoeficacia del victimario o imputado el actual sistema penal que viene imperando en el país - entiéndase por ello al conjunto de instituciones para la impartición de justicia penal, organización y funcionamiento de la justicia penal, y los procedimientos desplegados dentro de la institucionalidad de la justicia penal-y a su vez el influjo de ese sentido de autoeficacia personal en el cumplimiento de los acuerdos reparatorios, que en términos de determinación recíproca implica una mixtura interactiva entre ambiente, factores psicosociales y personales del sujeto y la conducta, proceso este identificado por el prominente psicólogo que desarrolló la teoría ${ }^{41}$, como reciprocidad triádica

41 Bandura, Albert, "Self-effiacy: Towards a unifying theory of behavioral change". Psychological Review, Núm. 84, 1977, California, Stanford University, pp. 191-215. 
del funcionamiento humano, donde el mundo y el comportamiento de los sujetos se interconectan uno al otro, refiriéndose así que

Bandura analiza la conducta humana dentro del marco teórico de la reciprocidad triádica, las interacciones recíprocas de conductas, variables ambientales y factores personales como las cogniciones... Según la postura cognoscitiva social, la gente no es impulsada por fuerzas internas ni controlada y moldeada automáticamente por estímulos externos. No, el funcionamiento humano se explica en términos de un modelo de reciprocidad triádica ${ }^{42}$.

En consideración a lo anteriormente referido, ninguno de los factores -ambiente, factores psicosociales y personales del sujeto y la conducta- son suficientes o determinantes por sí mismos, sino que su influencia es relativa-esto es, todos se ven mediados e interferidos unos con otros por mutuos influjos de diferente manera en función de cada sujeto y las circunstancias-; en tal sentido, todos poseen o adquieren importancia de determinación en el agenciar del ser humano (human agency) -capacidad de ejercitar el control sobre el funcionamiento de sí mismo y sobre los eventos que afectan la vida propia- generando procesos cognitivos (expectativas, creencias y pensamientos), las cuales finalmente influyen en la conducta, y a este respecto se señala que

Las personas con sus interacciones producen condiciones ambientales que, a su vez, afectan su comportamiento. Por otra parte, las experiencias generadas por el comportamiento también determinan las cogniciones del sujeto... Desde esta perspectiva, la preocupación por descubrir si la causa última es la conducta o el ambiente suele resultar inútil, ya que el mismo evento puede ser un estímulo, una consecuencia o un refuerzo ambiental, dependiendo de dónde empecemos el análisis ${ }^{43}$.

En correspondencia al planteamiento antecedido, puede considerarse que desde la teoría de la reciprocidad triádica formulada por el teorico referido ${ }^{44}$ la mirada en los análisis de interdependencia dinámica o interactiva de los factores ambientales, personales -eventos cognitivos, afectivos y biológicos- y acción -conducta manifiesta- en el ámbito de la justicia penal alternativa se han de centrar en el cómo se presentan los influjos introducidos por la autoeficacia del victimario en el cumplimiento de los acuerdos reparatorios, y a su vez la influencia que suelen ejercer las prácticas desplegadas desde la justicia reparadora sobre las creencias de capacidad

42 Schunk, Dale, Teorías del aprendizaje, México, D. F. Editorial Pearson Educación, 1997, p. 108.

43 Gozalo, Margarita; Benito León, "La promoción de la autoeficacia en el docente universitario", Revista Electrónica Interuniversitaria de Formación del Profesorado, Vol. 2, n. 1, 1999, p. 81.

44 Bandura, Albert, Pensamiento y acción. Fundamentos sociales. Barcelona, Ediciones Martínez Roca, S.A., 1987. 
de cambio, no reincidencia y cumplimiento íntegro de los acuerdos reparatorios, más allá de la idea de quién determina primero a quién, en virtud de las distintas formas de influencia creadas.

Así ha de indicarse que las creencias de autoeficacia que posee el victimario o sujeto activo de un hecho punible con respecto a su capacidad para hacerse responsable de los daños generados contra otros ciudadanos o propio Estado venezolano, desde su particular comportamiento lesivo, delictual, disociado, malhechor e imprudente, influyen sobre el modo de pensar, sentir, motivarse y actuar con respecto a los acuerdos reparatorios a los que desee plegarse en la oportunidad procesal -entiéndase por ello el momento en que tengan lugar, de acuerdo con las circunstancias de modo, tiempo y tipos penales-; en tal sentido, cuando mayor sea la creencia del sujeto imputado respecto a su capacidad de comprometerse en un posible arreglo penal con la víctima, mayor será su esfuerzo por rendir y cumplir efectivamente. No obstante, ha de tenerse en cuenta que tal condición

... se refiere a una situación específica, por lo cual es posible tener un alto sentido de autoeficacia ante un conjunto de circunstancias y, un grado bajo en otro conjunto de circunstancias. Por lo tanto no se considera una característica de personalidad estable, sino una característica que depende del contexto ${ }^{45}$.

En tal sentido, puede ocurrir que el victimario posea un elevado sentido de autoeficacia para evitar la reincidencia delincuencial, pero no para admitir un hecho punible del cual no se considera partícipe, toda vez que la posibilidad de acuerdo con el ofendido -víctima- surge luego de la admisión de la acusación realizada por el Ministerio Público, viéndose obligado a hacerlo para librarse de la pena de privativa de libertad así como de la estigmatización surgida del propio acto de ser procesado como delincuente; igualmente acontece con las actividades de darle cumplimiento a un acuerdo o someterse a un programa educativo de resocialización, donde la elección o rechazo del victimario depende en principio de su consideración de mostrarse mayormente hábil o incapaz para realizarla; por tal razón, se ha afirmado que

... cuando las condiciones ambientales obligan a emitir una conducta determinada, éstas se convierten en los principales determinantes del comportamiento; sin embargo, cuando los imperativos de la situación son débiles, los factores personales son los que actúan sobre dicha conducta ${ }^{46}$.

45 Busot, Ivonne, "Teoría de la Autoeficacia (A. Bandura): Un basamento para el proceso instruccional", Encuentro Educacional, Vol. 4, n. ${ }^{\circ}$ 1, Maracaibo, Universidad del Zulia, 1997, pp. 55.

46 Bandura, Alberto, 1986, citado por Verónica Ponce. Adaptación de la escala de autoeficacia BSES (Breastfeeding Self Efficacy Scale- Escala de Autoeficacia en la Lactancia Materna), Palermo, Universidad de Palermo, Trabajo Final para optar a la Licenciatura en Psicología Clínica, 2011, p. 9. 
Desde tal perspectiva, cuando el perpetrador o autor del hecho punible se muestra incurso en la incómoda situación - por ser una arbitraria exigencia del legislador- de hacer admisión de los hechos para acceder al beneficio procesal de no encarcelamiento -activado una vez se haya suscrito el acuerdo reparatorio con el ofendido o víctima- es el ambiente donde se encuentra inserto -llámese sistema de justicia penal acusatorio en general y admisión de la acusación presentada por el representante del Ministerio Público en particular- el generador de las condiciones para provocar el comportamiento asumido, de tal manera que viene a ser el factor ambiental el causante inmediato de la conducta manifestada, confiriéndole así muy poco margen de desempeño a los factores personales sobre las acciones desplegadas.

Por su parte, cuando se trate del caso de hallarse aún en fase de investigación, de no haberse encontrado suficientes elementos de convicción que lo incriminen en el hecho punible imputado - esto es, gozar del mérito favorable en la investigación- o no estar sometido a la presión de ser inculpado porque sencillamente no fue el perpetrador o quien llevo el acto delictual, los factores personales del victimario o autor del hecho punible harán funcionar su influencia, dotándolo de la capacidad requerida para ejercer dominio sobre los eventos que le afectan -enfrentar de manera libre o con el mínimo de ansiedad, estrés y depresión posible la experiencia adversa con la justicia penal-, lo que aumenta su creencia en sus capacidades o sentido de autoeficacia, para hacerle frente o manejar adecuadamente las situaciones desfavorables de la vida.

Los sujetos con mucha confianza en su sentido de eficacia tienden a considerar las situaciones adversas como algo temporal y por ello no suelen perder el control tan fácilmente, sino que se mantienen seguros de sí mismos por la creencia de ser eficaz en el manejo de su medioambiente y en la solución de los problemas manifiestos, implicándose mayormente en aquellas situaciones de vida demandantes de su atención inmediata -esfuerzo propio-, llegando a desplegar acciones -conducta motivada- por lograr lo que consideran que es su objetivo -en el caso particular frente al sistema de la justicia penal sería demostrar su inocencia para quedar totalmente exculpado- al efecto de mostrar mayor involucramiento en la investigación penal como lo pudieran a ser sus continuas declaraciones o disposición a ejercerlas, y a razón de ello se apuntala que

La autoeficacia ayuda a determinar las actividades en las que se puede participar (qué conductas se iniciarán), además de proporcionar información sobre el esfuerzo que se necesita para lograr los objetivos deseados y del tiempo que se está dispuesto a mantener ese esfuerzo pese a los obstáculos o experiencias adversas ${ }^{47}$.

47 Musitu, Gonzalo; Sofía Huelga, "Desarrollo comunitario y potenciación (empowerment)", en Introducción a la Psicología Comunitaria, Musito, Gonzalo; Juan Herrero, Leonor Cantera; Marisela Montenegro, Barcelona, Editorial uco, 2004, pp. 106. 
Ahora bien, en el caso concreto del acto reparador o concreción del acuerdo reparatorio, si bien los elementos vivenciales desfavorables - estar incurso en investigación penal, intentar acercarse a la víctima para responsabilizarse de su acción dañosa o lesiva y tratar de darle cumplimiento a los acuerdos suscritos- les permite a los victimarios o autores del hecho punible reconocer el impacto del daño generado en el otro, aprender a responsabilizarse de sus acciones antisociales y darse cuenta de cómo ellos mismos pueden constituirse en un sistema autoajustable a nivel personal y social -transformarse en un ser de oportunidades-; ha de indicarse que ni el procedimiento de la justicia reparadora ni sus operarios en Venezuela ayudan a instruirlo para la no reincidencia en hechos delictivos, abandonándolo a la suerte en su propio inframundo, desconociendo que

... la comisión de los delitos es una conducta aprendida a partir de la interacción social en el contexto de grupos pequeños; todo ello realizado mediante un proceso socializador en el que se transmiten los elementos culturales propios de sectores criminales; este aprendizaje incluye tanto las técnicas del crimen como la específica canalización de motivos, impulsos, racionalizaciones y actitudes $^{48}$.

Es precisamente en la primera experiencia delincuencial donde se abren todas las posibilidades para que el actor del hecho punible se muestre propenso a la carrera delictual o la desestime por completo, condición que va a depender en parte de lo gratificante -entendida como experiencia favorable por haber cometido la acción delictual sin llegar a responder a la justicia al valerse de sobornos, complicidad institucional, desaparición de las pruebas incriminatorias- o lo adverso haya podido ser el resultado alcanzado de la experiencia -está siendo investigado pudiendo ser acusado del ilícito perpetrado por los elementos de convicción ofrecidos en la investigación penal-y de los refuerzos positivos - se le insta a regenerarse y dársele una oportunidad procesal- o negativos -vejándolo y dándole privación de libertaddesde las estructuras institucionales.

En sí para que el sujeto victimario o perpetrador del hecho punible no se convierta en un delincuente competente -esto es no solamente realice la acción sino llegue a juzgarse capaz de acometer nuevamente delitos de cualquier naturaleza- las instituciones de la persecución penal -Ministerio Público, órganos de orden público e investigación criminal-así como de la justicia penal reparatoria -tribunales de controlhan de generarle al mismo la percepción de ineficacia para delinquir, atacando sus raíces o maneras específicas de reproducción como sería por ejemplo llegar a evitar darle entrada a los recintos penitenciarios -con las que se reproducen las conductas

48 Araújo, Carla, Medios Alternativos de Resolución de Conflictos en el Sistema Penal Venezolano, Maracaibo, Universidad del Zulia, Trabajo de Grado para optar al Título de Magister Scientiarum en Ciencias Penales y Criminológicas, 2009, p. 33. 
problemáticas, las agresiones, el consumo de drogas y de alcohol-fundamentándose tal acción en la gestión personal y la integración moral de los mismos.

Desde el punto de vista del sentido de la autoeficacia, la no reincidencia delictual no implica reinserción -cambiar de forma de vida y evitar la exclusión social-por cuanto ello alude a la condición personal con o sin apoyo familiar ${ }^{49}$ e institucional de adoptar valores pro-sociales, procurar formación educativa y cumplir autodisciplina laboral, sino de un elevado juicio o creencia personal sobre las capacidad de evitar la delincuencia, percibiéndose a sí mismo y frente a los demás como un perpetrador ocasional y no de carácter inmodificable, por ello resultaría todo un acto de injusticia empeñarse en enviarlo a prisión -la víctima, el juez o el representante del Ministerio Público- pudiendo emplearse medidas alternativas a la pena privativa de libertad si su acción trasgresora no menoscaba gravemente los intereses tutelados por el Estado venezolano ${ }^{50}$.

Las instituciones del sistema de justicia penal venezolano -llámense tribunales, fiscalías del Ministerio Público, órganos detectivescos y policiales- por ser garantes de los derechos-garantías de las personas en general -como trato humano y dignidad de la persona ${ }^{51}$ - se encuentran comprometidos con el funcionamiento psicológico saludable y competente de los victimarios; en tal sentido, les corresponde facilitarles el desarrollo de la autoeficacia, asegurándose que los esfuerzos realizados los compensen o gratifiquen de manera positiva, identificando y reconociendo los logros alcanzados en la realización y el mantenimiento de los comportamientos resocializadores ejercidos - persuasión verbal- así como también induciéndolos a la observación de la conducta de otros - llamados modelos- en la cimentación o fortalecimiento de la conducta deseada.

En cuanto a la labor resocializadora del sistema penal reparador -entiéndase por ella la transformación individual del victimario impulsada desde las instituciones vinculadas directamente con el ejercicio del control penal estatal para la reinserción social- ha de indicarse que es necesario que se impulse la implicación del autor del hecho punible o del delito perpetrado, en una labor educativa o productiva que

49 En opinión de Josep Cid, Martí Joel, El proceso de desistimiento de las personas encarceladas. Obstáculos y apoyos, Universidad Autónoma de Barcelona, 2011, p. 119, parece un factor por sí solo incapaz de dar a la persona un sentido de agencia que pueda sobreponerse a la intensa percepción de obstáculos.

50 Al decir de PRATT, John, Castigo y Civilización. Una lectura crítica sobre las prisiones y los regímenes carcelarios, Barcelona, Editorial Gedisa, 2006, p. 16, esta forma de proceder de la sociedad frente a los delincuentes, la hace considerar más civilizada, avanzada, y socialmente justa.

51 En el texto de PÉrez, Eric, Comentarios al Código Orgánico Procesal Penal (Concordado con el COPP de 12 de junio de 2012, Caracas, Vadell Hermanos Editores, 2016, se aprecia que el artículo 10 eiusdem establece la obligación a los funcionarios del sistema de justicia penal darle a toda persona en el proceso un tratamiento apegado al debido respeto de la dignidad inherente al ser humano. 
estimule su creatividad, sentido de dignidad humana, así como el esfuerzo por la honradez, favorezca el despliegue de sus potencialidades y lo mantenga centrado en la ocupación de actividades morales, se halle este inmerso o no en los ámbitos de procedencia de la justicia penal reparadora, por cuanto ello permite insertarlo de manera contundente a la vida renovada o transformada, señalándose acertadamente a este respecto que

El empleo... favorece el aprendizaje e interiorización de pautas de comportamiento, valores y hábitos, ayuda a la estructuración del día a día y genera cierta estabilidad emocional que reduce el conflicto en la convivencia. Es un aspecto a tener en cuenta a la hora de desarrollar procesos de socialización, promoviendo la formación tanto educativa, como laboral en las personas menos motivadas para ello ${ }^{52}$.

El sentido de autoeficacia del autor del hecho punible o perpetrador de delito dentro del sistema penal se fortalece o amplía con la interacción del ambiente social y el proceso de individualización que vive en forma favorable -sobredimensionándose en fortaleza, nivel y generalidad-, o desfavorable con lo cual se debilita -al reforzar la propagación de estados mentales y emocionales negativos- volviéndose menos intensa, por tal razón es tan significativo que desde la justicia penal reparadora que impera en el país -tendiente a humanizar la judicialización del conflicto penal- se eviten experiencias de descalificación, degradación, recriminación, opresión, incluso de deshumanización, generadoras de sentimientos tendientes a desatar respuestas hostiles y agresivas, con las cuales se hace casi imposible la conversión del victimario al inducirlo a la violencia delictiva.

Desde los fines resocializadores de la pena, donde los acuerdos reparatorios como medio procesal para realización de la justicia no únicamente buscan resarcir el daño infligido sino que el victimario se responsabilice de su comportamiento pernicioso contra alguno de los bienes que se encuentran protegidos por el Estado, no resulta procedente intimidar al victimario con la imposición de penas -como privativa de libertad- en caso de no llegar admitir su autoría o responsabilidad en fase acusatoria, que, como ha quedado demostrado, la práctica forense no dan respuesta o son poco eficaces para afianzar su sentido de eficacia personal, evitando que el mismo vuelva a reincidir; de allí que la implementación oportuna, adecuada y eficaz de los acuerdos reparatorios frente a delitos sin trascendencia desde el punto de vista penal se constituyan en el mecanismo idóneo para la prevención del delito.

52 PADRón, MARÍA, Expectativas de reinserción y desistimiento delictivo en personas que cumplen penas de prisión: factores y narrativas de cambio de vida, Universitad de Barcelona, Trabajo Final para optar al Título de Máster en Criminología, Política Criminal y Seguridad, Barcelona (España), 2014, p. 12 
Igualmente, desde la perspectiva del principio de la precaución -cuyos orígenes son de naturaleza ambiental trasladado al Derecho penal para encaminarse a ser uno de los referentes de la política criminal del Estado moderno ${ }^{53}$-, la implementación de los acuerdos reparatorios en forma oportuna -por cuanto han de ejercerse en el momento preciso-, adecuada -deben estar libre de vicios así como de actitudes denigrantes que vulneran la dignidad de la persona-y eficaz -cumplimiento íntegro de los preceptos normativos, así como de los acuerdos establecidos entre víctima y victimario a fin de darle terminación al conflicto penal instaurado-, con sus incidencias favorables sobre la autoeficacia no es sino una anticipación a reducir los riesgos sobre el incremento de la violencia, la criminalidad y el hacinamiento carcelario que acarrea la privativa de libertad sobre delitos de poca trascendencia penal.

Partiendo de la idea de que el Derecho penal -sustantivo y adjetivo- vigente protege aquellos aspectos que permitan en el sistema social concreto la realización personal, ha de indicarse que los acuerdos reparatorios sobre la concurrencia de delitos patrimoniales y culposos de poca significación o trascendencia penal, así como el desarrollo de comportamientos o actitudes respetuosas de la dignidad humana del imputado en los funcionarios del sistema de justicia, y la consecuente humanización de las penas, han de ser preferencia obligada en el sistema de justicia penal, ya que por medio de ellos se cimenta la imagen positiva del perpetrador del hecho punible hacia la vida transformada, así como también el despliegue de sus potencialidades humanas, de la cual el sentido de eficacia general y especifica en abandonar la delincuencia ha de ser la tarea a alcanzar mediante el desarrollo de una acertada política criminal que vaya acompasada con el propio sistema de justicia penal.

\section{A MANERA DE CONCLUSIÓN}

La autoeficacia es una poderosa herramienta psicológica que ha sido utilizada en los diferentes campos de la vida de los sujetos para modificar sus conductas a favor de un objetivo apropiado a su desarrollo personal, proyecto de vida y autorrealización, siendo de gran interés promoverla en el ámbito concreto de la justicia penal reparadora venezolana como nuevo paradigma de humanización de las penas a imponer con el propósito de lograr la consecución de sus fines, toda vez que es por medio de ella como el sujeto activo del hecho punible logra creerse mayormente seguro para no considerarse un delincuente, cumplir íntegramente las obligaciones que resultan

53 Para una mejor comprensión del principio de precaución dentro del ámbito penal véase GALÁN, ALFONSO, "La problemática utilización del principio de precaución como referente de la política criminal del moderno derecho penal. ¿Hacia un derecho penal del miedo a lo desconocido o hacia uno realmente preventivo?", Revista Justiça e Sistema Criminal, Vol. 7, Num. 12, 2015, pp. 107 164, que si bien es cierto no alude concisamente la dimensión reparadora de la justicia penal ayuda a hacerse una idea precisa de cómo ha de entenderse en los diferentes contextos donde tenga lugar el mismo. 
del acuerdo establecido con aval del representante del Ministerio Público y del juez de la causa, y llevar una vida renovada en la sociedad, cuyas creencias o juicios tienden a ser manifestación concreta de su conducta futura ${ }^{54}$.

La autoeficacia del sujeto en un alto nivel de sentido de cumplimiento con los compromisos contraídos ayuda a prevenir la inobservancia de los acuerdos reparatorios suscritos institucionalmente con la víctima, en razón a que su percepción de seguridad lo lleva a persistir en su esfuerzo -dotándolo de energizada motivación- pese a los inconvenientes o posibles obstáculos que pudieran presentársele al momento de efectuar la reparación o ejecutar el acuerdo -estar desempleado sin poder obtener ingresos para satisfacer los compromisos contraídos, no disponer por completo del monto acordado, o requerir los recursos económicos disponibles para satisfacer en forma inmediata problemas de salud suyos o de un familiar inmediato-, logrando de esta manera con gran ahínco sortear todas las adversidades presentadas para responder de la mejor manera en el compromiso asumido.

Ahora bien, pese a que la autoeficacia general -así como la específica- tiene notables incidencias dentro del marco de la justicia penal reparadora en Venezuela, en virtud que produce unos resultados favorables o desfavorables en el victimario o autor del hecho punible, los cuales a su vez exteriorizan sus repercusiones dentro del propio sistema de justicia, en función de la manera como se le encause o conlleve en forma personal e institucional a la misma, hay que apuntar que no se le ha considerado estratégica ni asertivamente, haciendo que los esfuerzos desplegados para descollar la lógica del castigo o la justicia basada en el dolor dentro del aparataje institucional, conseguir despertar el sentido de responsabilidad en el sujeto activo del delito, evitar futuros comportamientos delictivos, así como alcanzar eficacia en los recursos empleados por el Estado, se vuelvan exiguos e irrealizables.

En sí, los aspectos procedimentales y cognitivo-conductuales en los que se desenvuelve la justicia penal en el sistema judicial venezolano frente al victimario o autor activo del hecho punible al momento de investigar e instruir la causa, presentar la respectiva acusación e imponer la pena correspondiente, refuerzan el alejamiento sobre la autoeficacia general y específica de cambio personal, vida honrada, evadir la delincuencia y la reincidencia o cumplimiento de responsabilidades asumidas, por lo que puede afirmarse que tal contexto en nada favorece la paz social del país al aumentar los problemas sociales como recrudecimiento de la violencia, abandono de esfuerzos por superarse y comportamientos reincidentes, o del tipo institucional, entre los que se cuentan el hacinamiento carcelario y el congestionamiento judicial, del cual la mayoría de las sociedades latinoamericanas se hallan plagadas.

54 En el trabajo de Bandura, Albert, Pensamiento y acción. Fundamentos sociales. Barcelona, Ediciones Martínez Roca, S.A., 1987, se deja precisado como la autoeficacia influye sobre el modo en que el individuo anticipa, hace planes para su futuro y desarrolla su comportamiento. 
Los factores culturales - prácticas sociales promovidas por las concepciones morales, sociales y políticas fundamentadas en el castigo y la retribución como respuesta al delito- e institucionales del sistema penal restaurativo venezolano -control social penal más represivo que socializante sobre el victimario- refuerzan la ausencia de autoeficacia específica o debilidad de autoeficacia general que posee el autor del hecho punible, con los que se acrecientan los comportamientos dañosos hacia su integridad física -drogadicción, alcohol, tabaquismo, inanición por falta de alimentación, ingesta de alimentos con mínimo de salubridad, consumo de sustancias tóxicas, e incluso intentos de suicidio como manera de disminuir o extinguir su sentido de culpa, padecimiento y malestar consigo mismo-, así como también conductas delictivas, como agresiones, hurtos, robos y homicidios a sus coetáneos.

En este sentido, es importante que los órganos responsables de hacer posible la realización de la justicia penal reparadora en el país -Ministerio Público y Tribunales Penales en particular- puedan identificar e ir modificando esas actitudes o comportamientos institucionales de repulsión, desprecio e insensibilidad ostensibles contra el autor del hecho punible con la cual se induce la reducción del sentimiento de autoeficacia personal, al generar o reforzar en el mismo la retroalimentación de la imagen negativa, ocasionando que la desconfianza o las dudas que posee en su propia competencia para cooperar en su defensa sobre el hecho punible imputado, mantenerse sin sucumbir a la rigidez de la justicia penal o cumplir con acuerdos se incrementen, llevándolo a exteriorizar conductas negativas frente ante el tipo de situaciones a las que se enfrenta -como comportarse violentamente o como un delincuente de profesión.

\section{BIBLIOGRAFÍA}

AndRADE, XAVIER, "Consecuencias jurídicas de los derechos del procesado derivadas de su operatividad constitucional”, en Iuris Dictio, Vol. 15, Quito, Universidad de San Francisco, 2013, pp. 131-146.

Araúso, Carla, Medios Alternativos de Resolución de Conflictos en el Sistema Penal Venezolano, Maracaibo, Universidad del Zulia, Trabajo de Grado para optar al Título de Magister Scientiarum en Ciencias Penales y Criminológicas, 2009, pp.1-117.

Arbex, CARmen, "Modelos basados en el empoderamiento de los adolescentes y jóvenes", en PAD Servicio de Prevención de Adicciones. Francisco Lobo, MARI GonZÁlEZ, Madrid (España), Departamento de Prevención, Instituto de Adicciones de Madrid Salud, Ayuntamiento de Madrid, 2012, pp. 34-57.

Arcaya, Pedro, "Los Acuerdos Reparatorios", en Relación Criminológica, Núm. 13, Valencia, Universidad de Carabobo, 2005, pp. 61-82. 
ARÍAS, DORIS, "Reflexiones teóricas y prácticas sobre la reparación del daño y la justicia restaurativa", en Justicia restaurativa en Costa Rica: Acercamientos teóricos y prácticas. F. Bernal, S. CAstillo (Comp.), San José, Comisión nacional para el Mejoramiento de la Administración de Justicia, 2006, pp. 164-185.

Asamblea Nacional de la República Bolivariana de Venezuela, "Código Orgánico Procesal Penal”, Gaceta Oficial, n. ${ }^{\circ} 5.930$ del 4 de septiembre de 2009.

Asamblea Nacional de la República Bolivariana de Venezuela, "Ley contra la Estafa Inmobiliaria", Gaceta Oficial, n. . 39.912 del 30 de abril de 2012.

Asamblea Nacional de la República Bolivariana de Venezuela, "Ley de Reforma Parcial del Código Orgánico Procesal Penal”, Gaceta Oficial, n. ${ }^{\circ} 5.558$ del 14 de noviembre de 2001.

Asamblea Nacional de la República Bolivariana de Venezuela, "Ley de Reforma Parcial del Código Orgánico Procesal Penal”, Gaceta Oficial, n. o 349.708 del 4 de octubre de 2006.

Ávila, RAMIRO, “Inseguridad ciudadana y derechos humanos: Por la deconstrucción de un discurso securitista y hacia un nuevo derecho penal", en Nuevas Instituciones del Derecho Constitucional Ecuatoriano. Tomo II, DAVID CORDERo (comp.) Quito, Fundación Regional de Asesoría en Derechos Humanos (INREDH), 2010, pp. 45-82.

Bandura, Albert y Richard Walters, R., Aprendizaje social y desarrollo de la personalidad. Madrid, Alianza Editorial, 1974, pp. 155.

BAndura, Albert, "Perceived self-efficacy in the exercise of personal agency. The Psychologist", en Bulletin of the British Psychological Society, Vol. 2, 1989, pp. 411-424.

BANDURA, AlBERT, "Self-effiacy: Towards a unifying theory of behavioral change", en Psychological Review, Núm. 84, 1977, California, Stanford University, pp. 191-215.

Bandura, Albert, Pensamiento y acción. Fundamentos sociales. Barcelona, Ediciones Martínez Roca, S.A., 1987.

BeCARIA, CÉsar, De los Delitos y las Penas. Francisco Tomas (trad.), Madrid, Aguilar Ediciones, 1982.

BINDER, AlBERTO, Introducción al Derecho Procesal Penal. Buenos Aires, Editorial Ad-Hoc S. R. L., 1998, pp. 310. 
Busot, Ivonne, “Teoría de la Autoeficacia (A. Bandura): Un basamento para el proceso instruccional”, en Encuentro Educacional, Vol. 4, n. ${ }^{\circ}$ 1, Maracaibo, Universidad del Zulia, 1997, pp. 53-63.

CID, JoseP y MARTí, JOEL, El proceso de desistimiento de las personas encarceladas. Obstáculos y apoyos, Universidad Autónoma de Barcelona, 2011.

Comisión Legislativa Nacional, "Ley de Reforma Parcial del Código Orgánico Procesal Penal”, Gaceta Oficial, n. ${ }^{\circ} 37.022$ del 25 de agosto de 2000.

Congreso de la República de Venezuela, "Código Orgánico Procesal Penal", Gaceta Oficial, n. ${ }^{\circ} 5.208$ del 23 de enero de 1998.

Deym, José, "Crisis actual del Sistema Penitenciario y de la Política Penal”, en Pensar en Derecho, n. ${ }^{\circ}$ 2, 2016, pp. 239-282.

Fereira, George, El Ministerio Público frente a los Medios Alternos de Resolución de Conflictos como garantía penal para la Víctima. Maracaibo, Universidad Rafael Urdaneta, Trabajo de Grado para optar al Título de Abogado, 2013, pp. 1-94.

GALÁn, Alfonso, “La problemática utilización del principio de precaución como referente de la política criminal del moderno Derecho penal. ¿Hacia un Derecho penal del miedo a lo desconocido o hacia uno realmente preventivo?", en Revista Justiça e Sistema Criminal, Vol. 7, Núm. 12, 2015, pp. 107-164.

Garrido, Eugenio, Justicia Restauradora y Autoeficacia. 2008. [Disponible en: Blog CognitivoSocial.https://www.blogger.com/comment.g?blogID*=15167987278 5341549\&postID=601895418440737149. Consultado el 23 de Diciembre de 2016].

Garrido, Eugenio; Herrero, CArmen y Masip, Jaume, “Autoeficacia y Delincuencia”, en Psicothema, Vol. 14, Universidad de Salamanca, 2001, pp. 63-71.

GARRIDO, ISAAC y RoJO, CARMEN. "Motivación, cognición y rendimiento", en Revista de Psicología General y Aplicada, Vol. 49. n. ${ }^{\circ}$ 1, 1996, pp. 5-12.

Gómez, Jaime; Guillén, Natalie y Reneé, María, "Estudio Correlacional de la Autoeficacia Filial y la Relación Filial en Adolescentes", en Аjayu, Vol. 8, n. ${ }^{\circ}$ 1, Universidad Católica Boliviana San Pablo, 2010, pp. 1-20.

GonZÁlez, CASTOR, “La Usurpación de Marcas en Venezuela. Especial referencia a las medidas de Fronteras", en Revista La Propiedad Inmaterial, 2001, pp. 127-136. 
Gozalo, Margarita y León, Benito, "La promoción de la autoeficacia en el docente universitario", en Revista Electrónica Interuniversitaria de Formación del Profesorado, Vol. 2, n. ${ }^{\circ}$ 1, 1999, pp. 79-90.

Han, Pablo; PÁrraga, Jesús y Scarano, María, "Los Acuerdos Reparatorios y su aplicación en el nuevo proceso penal venezolano", en Capítulo Criminológico, Vol. 28, n. . 2, Maracaibo, Universidad del Zulia, 2000.

MAier, Julio, “La Víctima y el Sistema Penal”, en Jueces para la Democracia, n. 12, Madrid, 1991, pp. 33.

Méndez, YoAhana, Actitudes hacia la justicia restaurativa y estrategias de afrontamiento en jóvenes vinculados al sistema de responsabilidad penal adolescente (SRPA), Trabajo de Grado para optar al Título de Magíster en Psicología Jurídica, Bogotá, D.C., 2014, pp. 1-173.

Menéndez, Belén; Rodríguez, María; Becedóniz, Carlos y Bernardo, Ana, "Influjo del contexto escolar y grupo de iguales en el comportamiento reincidente de menores infractores", en Psicología jurídica. Entorno Judicial y Delincuencia, Francisco Rodríguez, Carolina Bringas, Francisca Fariña, Ramón Arce, Ana BERnARdo (eds.), Oviedo, Ediciones de la Universidad de Oviedo, 2008, pp. 206-212.

Moscoso, Manolete, "Hacia un análisis cognitivo del cambio conductual: El comportamiento social pro activo", en Revista de Psicología, Vol. XIV, n. ${ }^{\circ} 1,1996$, pp. 47-72.

Musitu, Gonzalo y Huelga, Sofía, "Desarrollo comunitario y potenciación (empowerment)", en Introducción a la Psicología Comunitaria, GonZalo Musito, Juan Herrero, Leonor Cantera, Marisela Montenegro, Barcelona, Editorial UCO, 2004, pp. 98-115.

PADRÓN, MARÍA, Expectativas de reinserción y desistimiento delictivo en personas que cumplen penas de prisión: factores y narrativas de cambio de vida, Universitad de Barcelona, Trabajo Final para optar al Título de Máster en Criminología, Política Criminal y Seguridad, Barcelona (España), 2014, pp. 1-124.

Pérez, Erick, Comentarios al Código Orgánico Procesal Penal, Caracas, Vadell Hermanos Editores, 2001.

PONCE, VERÓNICA, Adaptación de la escala de autoeficacia BSES (Breastfeeding Self Efficacy Scale-Escala de Autoeficacia en la Lactancia Materna), Palermo, Universidad de Palermo, Trabajo Final para optar a la Licenciatura en Psicología Clínica, 2011, pp. 1-48. 
PRATT, John, Castigo y Civilización. Una lectura crítica sobre las prisiones y los regímenes carcelarios, Barcelona, Editorial Gedisa, 2006.

Presidencia de la República Bolivariana de Venezuela, "Decreto con Rango, Valor y Fuerza de Ley del Código Orgánico Procesal Penal”, en Gaceta Oficial Extraordinario n. ${ }^{\circ} 6.078$ del 15 de junio de 2012.

Quintero, Gonzalo, Los Delitos contra el Patrimonio, Catalunya, Universitat Oberta de Catalunya, 2012, pp. 1-68.

Roxin, Claus, Autoría y Dominio del hecho en el Derecho Penal. Madrid, Ed. Jurídicas y Sociales, 2000.

RuIZ, FERnANDO, "Influencia de la autoeficacia en el ámbito académico", en Revista Docencia Universitaria, n. ${ }^{\circ}$ 1, enero-diciembre, 2005, pp. 1-16.

Sala Constitucional del Tribunal Supremo de Justicia, Sentencia n. ${ }^{\circ} 776$ del 9 de abril de 2002.

Schunk, Dale, Teorías del aprendizaje, México, D. F. Editorial Pearson Educación, 1997, pp. 108.

VidELA, LinO, "Los acuerdos reparatorios a la luz del concepto de reparación", en Revista de Estudios de la Justicia, n. ${ }^{\circ} 13,2010$, pp. 293-321.

VILlarReal, KARLA, “La víctima, el victimario y la justicia restaurativa”, en Rivista di Criminologia, Vittimologia e Sicurezza, Vol. 7. n. ${ }^{\circ}$ 1, 2013, pp. 43-57. 